\title{
Fruit structure and some details of fruit morphogenesis in subfamily Tripterygioideae Loes. (Celastraceae R. Br.)
}

\author{
I. A. Savinov, E. V. Solomonova \\ Moscow State University of Food Production, Volokolamskoe shosse, 11, Moscow, 125080, Russia. E-mail: savinovia@mail.ru
}

Key words: Celastraceae, fruit structure, morphogenesis, phylogenetic relationships, Platypterocarpus, Plenckia, Ptelidium, Rzedowskia, seed structure, Tripterygioideae, Tripterygium, Wimmeria, winged nut, winged pyrenarium, Zinowiewia.

Summary. Fruit structure and morphogenesis in subfamily Tripterygioideae Loes. (Celastraceae R. Br.) are presented. Fruits are either with 2, 3 or 5 lateral wings, nested along the fruit, or with one apical wing (on the fruit's sides and its apex). The wings are wide or narrow, membranous; the body of the fruit is shorter than its wings. The wings usually possess a net of vascular bundle derivates. The topography of vascular bundles defines the way of pericarp expansion. For all examined fruits style on the apex always remains. Peculiarities of pericarp structure and development suggest morphogenetical type of the fruit in Tripterygioideae - pseudomonomerous unilocular one-seeded winged pyrenarium with a pyrene, which can be formed by 3 to 5 layers of tangential elongated macrosclereids (in many examined taxa). Fruit type of Ptelidium is uni- or bilocular and one(two)-seeded nut, because its pericarp is lignified entirely. Fruit of Rzedowskia has only one layer of radially elongated sclereids in endocarp. Seeds of all examined species are small, without aril. Two genera appeared to be more isolated - Ptelidium and Rzedowskia. All examined taxa have demonstrated one special evolutional trend in common - the reduction of the number of seeds per fruit and the development of wings as an adaptation to the dispersal by wind. According to the latest molecular data, such fruit types have been formed in Celastraceae at least six times in the course of evolution.

\section{Структура и некоторые черты морфогенеза плодов представителей подсемейства Tripterygioideae Loes. (Celastraceae R. Br.)}

\author{
И. А. Савинов, Е. В. Соломонова
}

ФГБОУ ВО «Московский государственный университет пищевых производств», Волоколамское шоссе, 11, Москва, 125080, Россия. E-mail: savinovia@mail.ru

\begin{abstract}
Ключевые слова: крылатый пиренарий, крылатый орех, морфогенез, подсемейство Tripterygioideae, родственные связи, семейство Celastraceae, структура плодов, структура семян, Platypterocarpus, Plenckia, Ptelidium, Rzedowskia, Tripterygium, Wimmeria, Zinowiewia.
\end{abstract}

Аннотация. Представлены результаты сравнительного изучения структуры плодов и некоторые черты их морфогенеза у представителей подсемейства Tripterygioideae Loes. (Celastraceae R. Br.). Плоды изученных видов несут 2, 3 или 5 боковых крыловидных выростов вдоль тела плода, либо только 1 апикальное крыло. Крылья широкие или узкие, пленчатые, тело самого плода короче его крыла. Крылья обычно содержат сеть дериватов проводящих пучков. Топография пучков демонстрирует путь (направление) разрастания перикарпия в процессе развития. Плоды всех изученных видов содержат остатки столбика на верхушке. Особенности структуры и развития перикарпия подтверждают, что морфогенетический тип плода у видов Tripterygioideae псевдомономерный одногнездный односеменной крылатый пиренарий с косточкой, которая образована 3-5 слоями тангентально расположенных макросклереид (во многих изученных видах). Тип плода у видов Ptelidi- 
um - одно- или двухгнездный и одно(двух-)семенной орех, поскольку его перикарпий полностью лигнифицирован. Плод у Rzedowskia имеет только один слой радиально вытянутых склереид в эндокарпии. Семена всех изученных видов очень мелкие, без ариллуса. По результатам исследования два рода оказались более изолированными - Ptelidium и Rzedowskia. Все изученные представители демонстрируют одну специфическую эволюционную тенденцию - редукцию числа семян в плоде и развитие крыльев как адаптацию к распространению их ветром. Согласно последним молекулярным данным, такие типы плодов формировались в ходе эволюции семейства Celastraceae как минимум шесть раз.

\section{Introduction}

Just like many other families of angiosperms, Celastraceae has changed greatly in their circumscription following recent molecular phylogenetic studies (APG III, 2009). Additional detailed and comprehensive study of different aspects of plant morphology will be required in order to obtain a reasonable, accurate picture of intra-familial relationships. In particular, there is interest to fruit and seed structure and development in the subfamily Tripterygioideae Loes., which is characterized by indehiscent winged fruits (Savinov, Solomonova, original data). In literature, the description of fruit morphology and anatomy for the specific taxon in detail is missing to date, except for some general information. So, some interesting materials on the morphology of wings with details of their venation for fin-winged fruits in some Celastraceae (Platypterocarpus, Stackhousia, Tripterococcus, Tripterygium, Wimmeria) are presented by S. Manchester and E. O'Leary (2010). In fundamental book on the fruit morphogenesis in Magnoliophyta (Bobrov et al., 2009) interpretation of fruits in Tripterygioideae is given as the pseudomonomerous upper one-seeded syncarpous winged pyrenariums with pyrene of unknown nature, and fruit of the Rzedowskia is included to upper nuts.

According to Th. Loesener (1942) with supplements by Dunkley et Brenan (1948, cit.: Robson et al., 1994) and by F. Gonzalez-Medrano (1981), there are 7 woody genera attributable to Tripterygioideae subfamily. These genera consist of 40 species, distributed in Central and South America, Tropical East Africa, Madagascar and eastern Asia (Simmons, 2004). However, Theodor Loesener's subfamilies and tribes of Celastraceae s. str. are generally not supported by cladistic morphological analysis (Simmons, Hedin, 1999), as well as by molecular phylogenetic data (Simmons et al., 2001a-b, 2008, 2012a-b; Coughenour et al., 2010, 2011). Finally, M. P. Simmons with colleagues came to the conclusion that the Tripterygioideae was an artificial subfamily. So, the actual problem is a search for new morphological characters and their comparison with available data on molecular phylogenetics.

\section{Materials and methods}

Fruits for the present study (developing and mature) were collected in botanical gardens (see App. A) or received by authors from carpological collections and herbaria (K, LE, MHA, P) and fixed in $70 \%$ ethanol. When possible, several samples of fruits and seeds of each species were studied. Specimens of fruits and seeds were used for light microscopy. Cross sections of fruits and seeds in the middle part were taken according to classical anatomical methods (Barykina et al., 2000). Commonly accepted terminology was used in the descriptions of fruits and seeds (Melikjan, Devjatov, 2001). Fruits and seeds of 6 genera and 12 species were examined; all of them traditionally belong to the Tripterygioideae subfamily: Plenckia Reissek (1 species), Ptelidium Thouars (2 species), Rzedowskia Medrano (1 species), Tripterygium Hook. f. (3 species), Wimmeria Schltdl. et Cham. (4 species), Zinowiewia Turcz. (1 species). Specimens studied are presented in Appendix A. In comparative aspect, the structure of fruits and seeds for 39 genera and 102 species of other Celastraceae was previously studied (Savinov, 2012).

\section{Results \\ Plenckia populnea Reiss.}

Fruit - one-seeded one-winged, greenish brown in color, up to $35 \mathrm{~mm}$ long and $7 \mathrm{~mm}$ wide (Fig. 1a, i). Groups of vascular bundles are found to pass through the center of the wing. The pericarp consists of 10-12 cell layers (Fig. 2a). The exocarp is made of a single layer presented on rectangular cross-section, tangentially elongated cells with thickened outer and (to a lesser extent) side walls. The mesocarp is a few-layered, formed by three to four layers of phlobaphene-containing, tangential elongated parenchyma cells. In mesocarp, the derivatives of vascular bundles are separate. The endocarp is differentiated in two topographic zones. The outer area consists of five to six layers of tangentially elongated macrosclereids, and the 


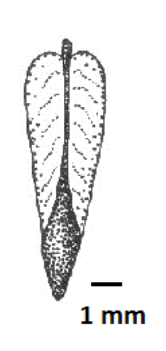

a

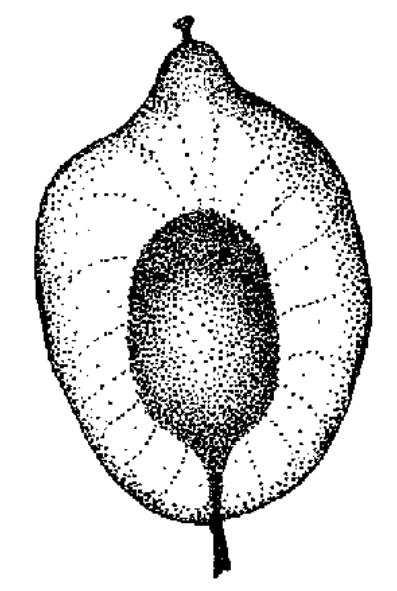

b

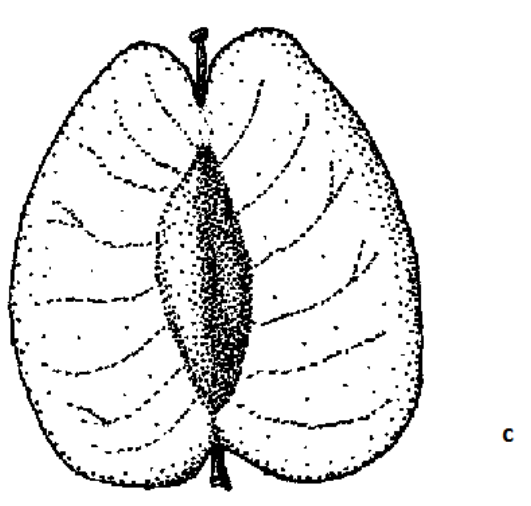

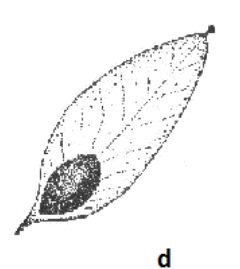

d
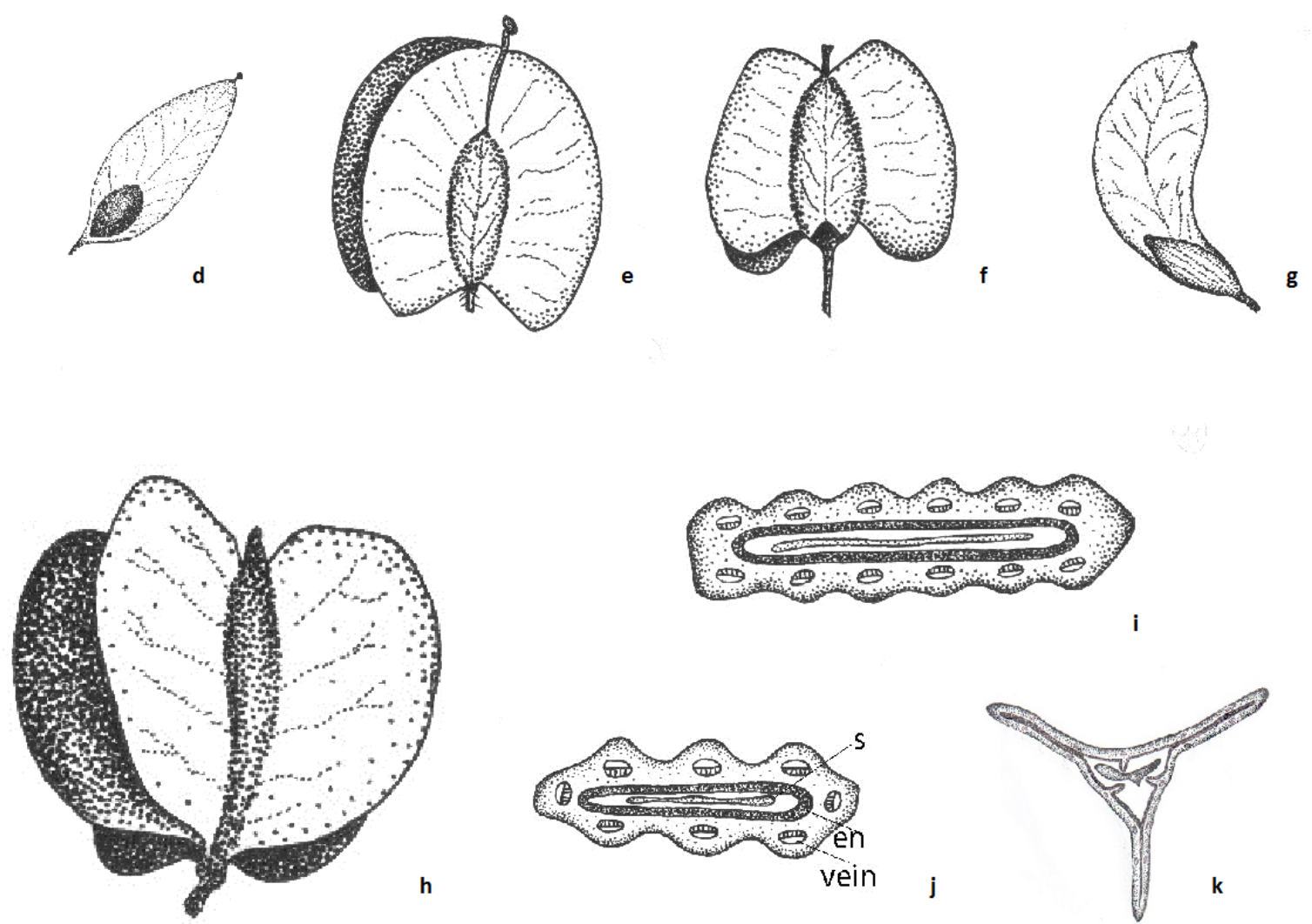

\section{i}
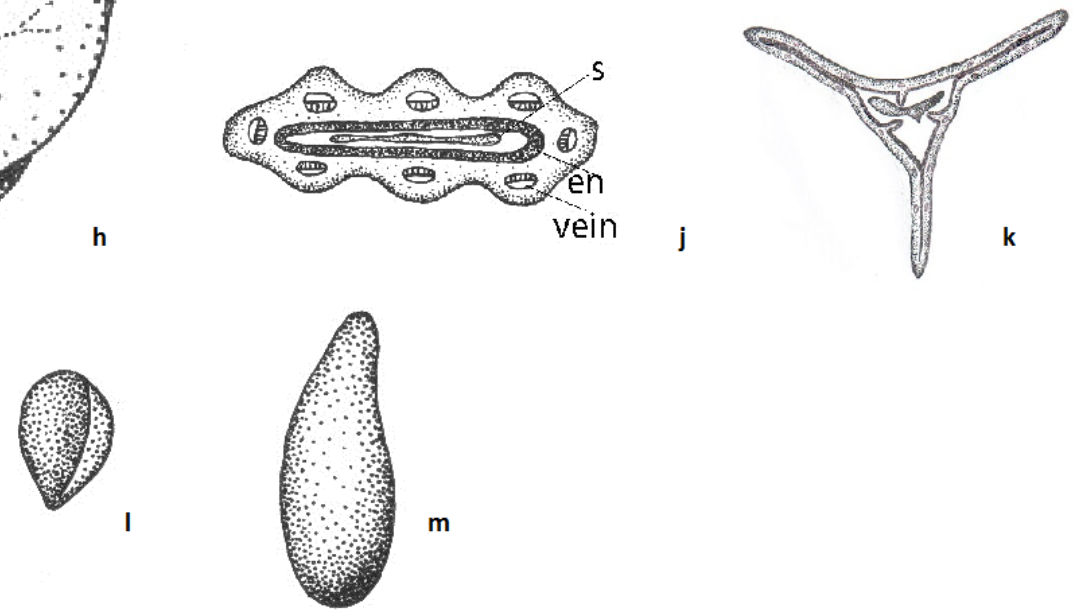

Fig. 1. Fruit and seed morphology of Tripterygioideae. Fruits: a - Plenckia populnea Reiss.; b - Ptelidium ovatum Poir.; c - P. samberanensis R. Capeen.; d - Rzedowskia tolantonguensis Medrano; e - Tripterygium regelii Sprague et Takeda; f - Wimmeria persicifolia Radlk.; g - Zinowiewia integerrima Turcz.; $\mathrm{h}$ - Platypterocarpus tanganyikensis Dunkley et Brenan (according to Robson et al., 1994); transverse section of fruit: $\mathrm{i}$ - Plenckia populnea; $\mathrm{j}-$ Zinowiewia integerrima; $\mathrm{k}$ - Tripterygium regelii; seeds: 1 - Tripterygium regelii; $\mathrm{m}$ - Wimmeria persicifolia. Scale bar $=1$ $\mathrm{mm} ; \mathrm{s}$ - seed, vein - vascular bundles, en - endocarp. 
internal one - of one layer of discolored cells with evenly thickened walls.

Seed is oval, elongated, brownish, up to 15 $\mathrm{mm}$ long and $3 \mathrm{~mm}$ wide. The seedcoat consists of 10-12 layers (Fig. 3a). The exotesta is composed of a single layer, represented by phlobaphenecontaining, rectangular in cross section, cells with markedly thickened outer walls. The cuticle is thin. The mesotesta is formed by four to five layers of tangentially elongated, phlobaphene-containing parenchyma cells. The endotesta is presented by a single layer of small cells, slightly elongated tangentially. The exotegmen is a single layer, which consists of small tabular cells with uniformly thickened walls. Meso- and endotegmen presented by 3(4) layers are made of slightly compressed, phlobaphene-containing parenchymatous cells.

\section{Ptelidium samberanensis R. Capeen.}

Fruit - one-seeded two-winged, app. $60 \mathrm{~mm}$ long, sometimes with underdeveloped third wing (Fig. 1c). The pericarp consists of 8-9 layers (Fig. 2b). Exocarp is presented by one layer of very small cells with uniformly thickened walls. Mesocarp consists of 3 layers of cells with evenly thickened (poorly lignified) walls. Endocarp is formed by 4 layers of macrosclereids. Macrosclereids are elongated in tangential direction forming a single supporting cord.

Only small seed is located in the locule of the fruit. Unfortunately, it was not possible to obtain acceptable sections for anatomical study from a single specimen.

\section{Rzedowskia tolantonguensis Medrano}

Fruit - one-seeded, with vascularized wing, extended from the apex of the fruit ("samara"), 12 $\mathrm{mm}$ long, $6 \mathrm{~mm}$ wide in the middle part (Fig. 1d). The pericarp is not very thick, only 6-7 layers of cells (Fig. 2c). Exocarp consists of a single layer of cells almost square in cross section, with thickened outer walls. The mesocarp is not differentiated and formed by 4 layers of small parenchymatous cells. Endocarp forms a supporting tissue strand, which consists of a single layer of large sclereids, elongated in the radial direction. The inner zone of the endocarp (1 layer) consists of markedly compressed cells.

Seed is very small. Spermoderm consists of 4(5) layers of cells (Fig. 3b). Exotesta is formed by a single layer of very large cells with thickened outer walls. They contain phlobaphene and occupy almost $1 / 2$ of spermoderm. Mesotesta forms 2 layers of parenchyma cells, slightly elongated in tangential direction. Exotegmen consists of a single layer of fibrous cells. The other layers of tegmen are not preserved in mature spermoderm. Endosperm cells are quite large.

\section{Tripterygium regelii Sprague et Takeda}

Fruit - one-seeded, three-winged, with remains of a long style at the top (Fig. 1e, k). Wings of the fruit are broad, longitudinal. The body of the fruit is almost equal to its entire length. The pericarp consists of 12-13 layers (Fig. 2d). Exocarp is represented by a single epidermal layer of small cells, the surface of which has a homogeneous, smooth cuticle layer. Mesocarp is formed by 7 layers of small parenchymatous cells containing phlobaphene. Endocarp is not differentiated and consists of 4-5 layers of medium-sized macrosclereids, elongated in tangential direction, located very tightly, forming a solid strand. It stretches through the whole wing of the fruit.

Seed is small (Fig. 11). Spermoderm consists of 7 layers (Fig. 3c). Exotesta is formed by a single layer, presented by several cells elongated in tangential direction, with thickened walls. Layers of cuticle and epicuticular wax are pronounced. Mesotesta is formed by 3 layers of parenchymous cells containing phlobaphene. Endotesta is not expressed. Exotegmen consists of a single layer of small sclereids. The other two layers of the tegmen are represented by small, compressed parenchymous cells.

\section{Wimmeria persicifolia Radlk.}

Fruit is one-seeded, with three longitudinal winglike appendages, about 10-12 mm long (Fig. 1f). Pericarp consists of 8 to 9 layers (Fig. 2e). Exocarp is one-layered, presented by small cells rectangular in cross section. The cuticle layer is uniform. Mesocarp is formed by 5 layers of large-celled parenchyma. Endocarp consists of 2 to 3 layers of macrosclereids elongated in tangential direction.

Seed is oblong, about 7-8 mm long, dark red (Fig. $1 \mathrm{~m}$ ). Spermoderm is of few layers (6 to 7 ), slightly differentiated (Fig. 3d). Exotesta is formed by a single layer of small cells, rectangular in cross section. Mesotesta is presented by 4 layers of smallcelled parenchyma, the cells of which are slightly compressed. Exotegmen is a single layer of small sclereids.

\section{Zinowiewia integerrima Turcz.}

Fruit is one-seeded, with one wing, pale yellow in color (body of the fruit is brownish), $20-23 \mathrm{~mm}$ long and $5 \mathrm{~mm}$ wide (Fig. 1g, j). The body of the 
fruit is about $10 \mathrm{~mm}$ long and $2-3 \mathrm{~mm}$ wide. Wing possesses a network of vascular bundles. Main bundle has a cusp at the apex of the fruit. Pericarp consists of 16-17 layers (Fig. 2f). Exocarp is singlelayered, presented by small tabular cells with U-shaped wall thickenings (external and internal). Cuticle on their surface is deposited as a thin uniform layer. Mesocarp consists of 9 to 10 layers of medium-sized, almost isodiametric parenchymal cells. In the mesocarp, very large vascular bundles derivatives apparently performing the supporting function, are seen. Endocarp is differentiated in two topographic zones. The outer zone is formed by 4-5 layers of short macrosclereids, which form a continuous supporting strand (they are profusely penetrated by pore canals); and the inner zone is of one layer, consisting of colorless cells of the inner epidermis with markedly thickened walls.

Seed is medium-sized, oval, about $7 \mathrm{~mm}$ long and $1.5-2 \mathrm{~mm}$ wide. Spermoderm is formed by 8 to 10 cell layers (Fig. 3e). Exotesta is of a single layer, presented by small papillate cells, with walls abundantly impregnated by phlobaphene. External sides of their walls are thickened. Cuticle is presented by a thin layer. Mesotesta is formed by large, tangentially elongated parenchymal cells. They are abundantly filled with phlobaphenes. Endotesta is obsolete. Exotegmen is represented by a single layer, of tabular cells with uniformly thickened walls. The remaining 2 layers of parenchymal cells of tegmen are slightly compressed. Endosperm is fairly abundant. Embryo is small but well differentiated.
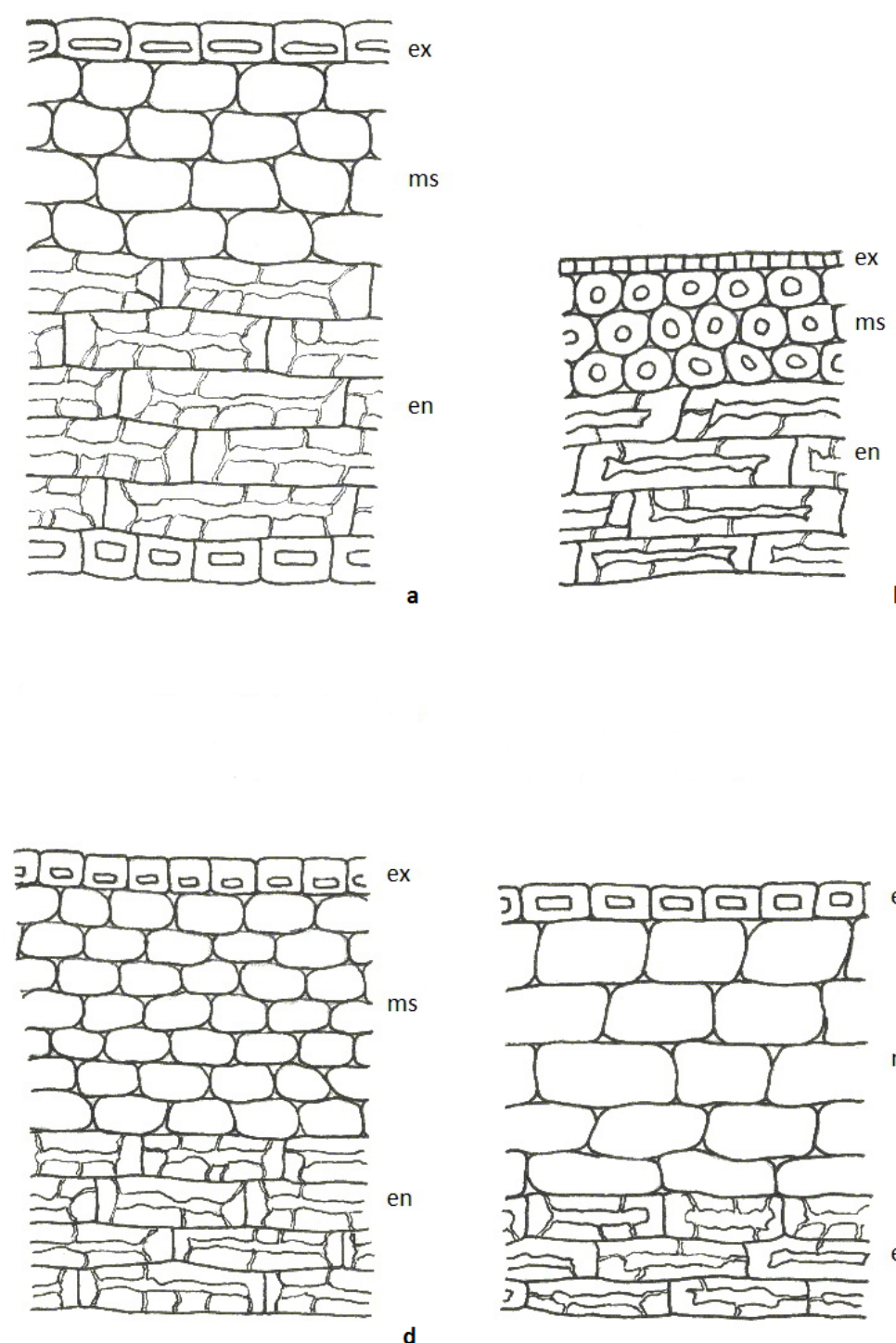

$0,1 \mathrm{~mm}$
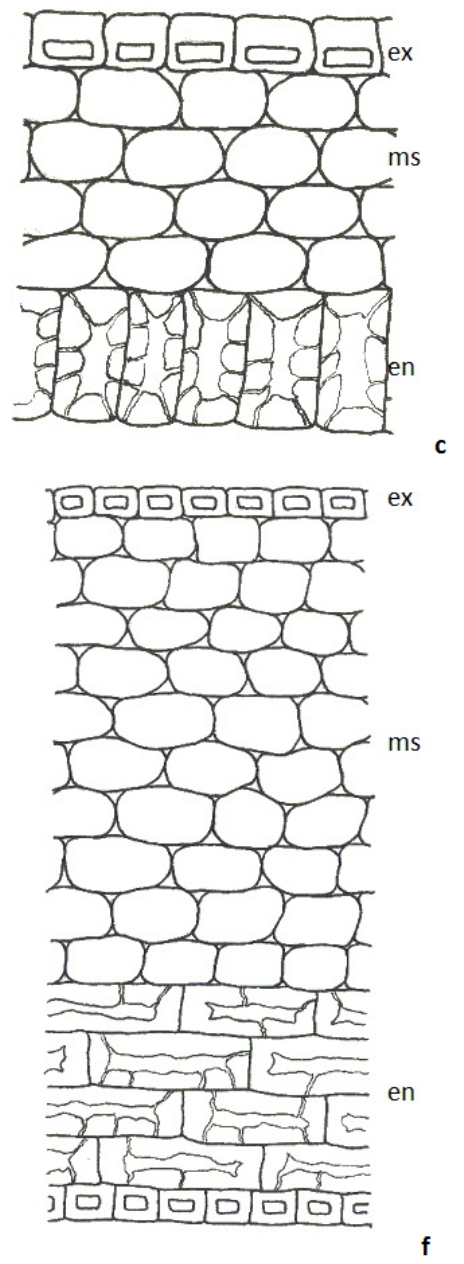

Fig. 2. Fruit anatomy of Tripterygioideae (cross sections): a - Plenckia populnea; b - Ptelidium samberanensis; c Rzedowskia tolantonguensis; d - Tripterygium regelii; e - Wimmeria persicifolia; $\mathrm{f}$ - Zinowiewia integerrima. Scale bar $=0.1 \mathrm{~mm}$; ex - exocarp, ms - mesocarp, en - endocarp. 


\section{Discussion}

General fruit morphology. All seven genera are characterized by indehiscent unilocular (rarely bilocular - Ptelidium) winged fruits ("samara"). Fruit size: the length of the wing ranging from 12 $\mathrm{mm}$ in Rzedowskia to $55 \mathrm{~mm}$ in Platypterocarpus; the width of the wing ranging from $5-6 \mathrm{~mm}$ in Rzedowskia to $36 \mathrm{~mm}$ in Platypterocarpus. The shape of the fruit may be: 1) discoid (Ptelidium); 2) "sailing" one-winged samara (Plenckia, Zinowiewia); 3) fruits with 3-5 lateral wings (Platypterocarpus, Tripterygium, Wimmeria) (Fig. $1 \mathrm{a}-\mathrm{g})$. Fruits are either with 2, 3 or 5 lateral wings, nested along the fruit, or with one apical wing (on the fruit's sides and its apex). The wings are wide or narrow, membranous; the body of the fruit is shorter than its wings. The wings usually possess a net of vascular bundle derivates. The topography of vascular bundles defines the way of pericarp expansion. Such a fruit type may be considered as an adaptation to anemochorous dispersal.

Pericarp structure. Pericarp is differentiated into outer one-layered exocarp, middle parenchymous mesocarp and inner fibrous endocarp. The only exception is the pericarp of Ptelidium which is lignified entirely. Fruits contain a pyrene, which can be formed by 3 to 5 layers of tangential elongated macrosclereids (in many examined taxa) or only layer of radially elongated sclereids (Rzedowskia). Obviously, the pyrene is formed by the endocarp. Such pericarp structure is unknown for other groups of Celastraceae (Savinov, Solomonova, original data), what allows us to assume that this character is unique for the family (Fig. 2a-f).

Seed structure. Seeds are very small, with a well-developed embryo and copious endosperm, without arils. The thin seedcoat (spermoderm) is derived from both ovular integuments. It is differentiated into the multi-layered testa and the few-layered tegmen. The few-layered spermoderm is correlated with a pronounced, well-developed pericarp with inner zone of sclereids, forming the pyrene (Fig. 3a-e).

Some details of fruit morphogenesis. Apparently, the morphogenetical type of the fruit in Tripterygioideae is a pseudomonomerous oneseeded winged pyrenarium with remains of style (except in the genus Ptelidium). Wings of the fruit are formed due to radial expansion of the pericarp in the area of the carpels' back side along the fruit longitudinal axis. Such fruits are known to develop from an oligomerous gynoecium (of 2 to 3 or 4 to 5 carpels) with 2(4-8) ovules in each locule. Underdevelopment of locules often takes place. As a result, only one locule is often pronounced and incomplete partitions are preserved in mature fruits
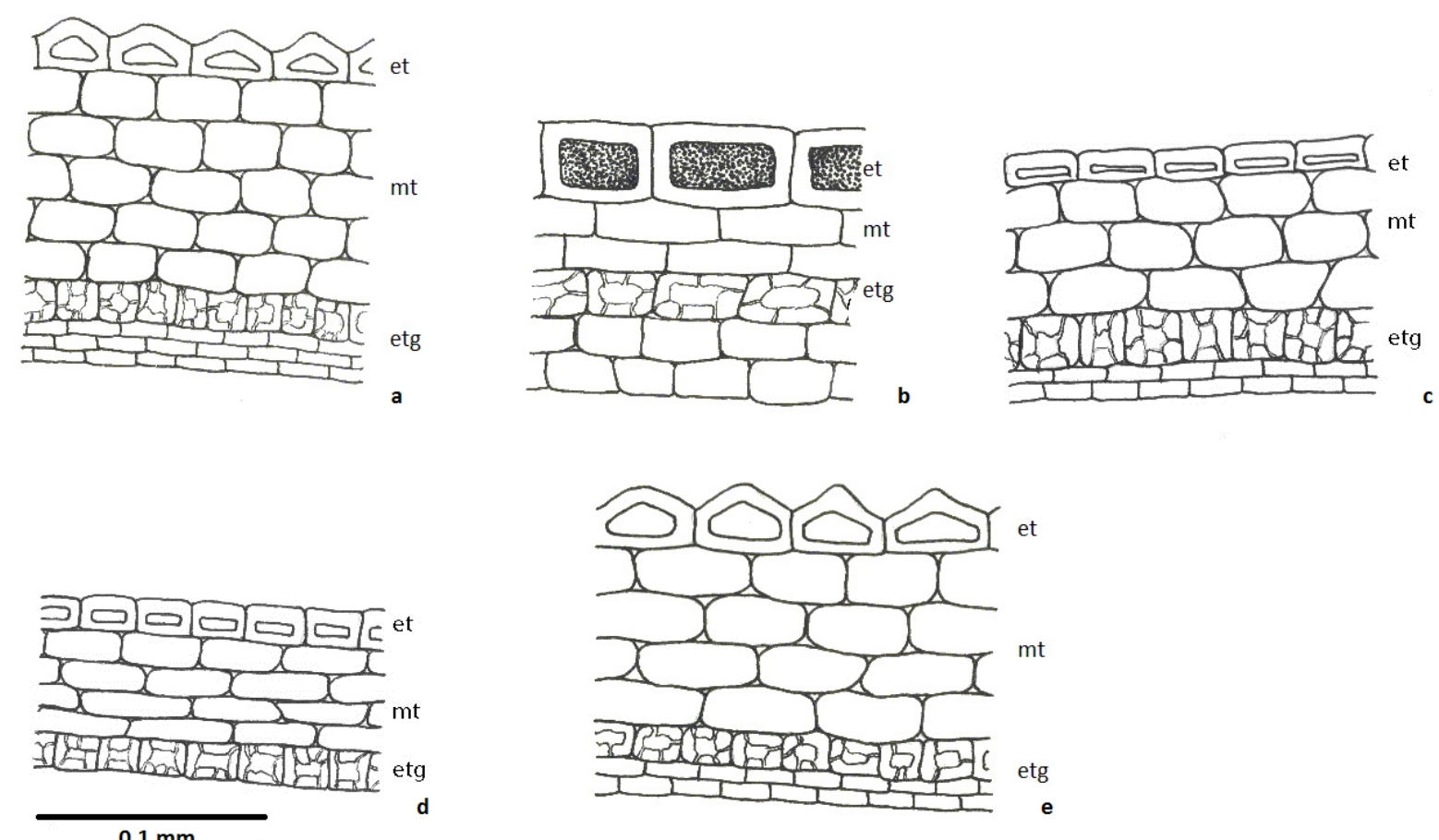

Fig. 3. Seed anatomy of Tripterygioideae (cross sections): a - Plenckia populnea; b - Rzedowskia tolantonguensis; c - Tripterygium regelii; d - Wimmeria persicifolia; e - Zinowiewia integerrima. Scale bar $=0.1 \mathrm{~mm}$; et - exotesta, $\mathrm{mt}$ - mesotesta, etg - exotegmen. 
(Fig. 1i-k). The number of wings in the fruit usually corresponds to the number of carpels that form the gynoecium.

So, morphogenetical type of the fruit in Tripterygioideae is pseudomonomerous unilocular one-seeded winged pyrenarium with a pyrene. Fruit type of Ptelidium is uni- or bilocular and one(two)seeded nut, because its pericarp is lignified entirely.

We compared our findings with the results of molecular phylogenetic studies of the subfamilies Cassinoideae and Tripterygioideae (Simmons et al., 2012a). Here, Tripterygioideae subfamily is splitted into 6 clades, and they are related to different representatives of Cassinoideae and even Celastroideae.
As previously demonstrated in our research (Savinov et al., 2015), winged fruits of the family Celastraceae can be divided into four types based on the nature of wing-like outgrowths, and these types are characterized appropriate clades very well. Type I is more heterogeneous, and we were able to distinguish two subtypes: anemochorous (Type IA) and non-anemochorous (Type IB). They differ quite well in the pericarp structure and morphogenetic type of fruit - pyrenarium or capsule respectively. The genus Ptelidium is more isolated in comparison with others, because its pericarp is lignified entirely and its fruit type is a winged nut. Based on molecular data (Simmons et al., 2012a), we came to conclusion that winged fruits of Tripterygioideae were formed on

Table

Summary of fruit types in Tripterygioideae in comparison with main clades of Celastraceae

\begin{tabular}{|c|c|c|c|c|c|c|}
\hline $\begin{array}{l}\text { Family or sub- } \\
\text { family }\end{array}$ & Genus & $\begin{array}{l}\text { The } \\
\text { number } \\
\text { of species } \\
\text { examined / } \\
\text { Total spe- } \\
\text { cies }\end{array}$ & Distribution & Habit & Pericarp structure & Fruit type \\
\hline \multirow[t]{6}{*}{ Tripterygioideae } & Plenckia & $1 / 4$ & $\begin{array}{l}\text { Southern } \\
\text { America }\end{array}$ & $\begin{array}{l}\text { Trees or } \\
\text { shrubs }\end{array}$ & $\begin{array}{l}\text { Few-layered; tan- } \\
\text { gential elongated } \\
\text { macrosclereids }\end{array}$ & $\begin{array}{l}\text { Winged } \\
\text { pirenarium }\end{array}$ \\
\hline & Ptelidium & $2 / 2$ & Madagascar & $\begin{array}{l}\text { Scandent } \\
\text { or erect } \\
\text { shrubs }\end{array}$ & $\begin{array}{l}\text { Few-layered; } \\
\text { lignified entirely }\end{array}$ & Winged nut \\
\hline & Rzedowskia & $1 / 1$ & Mexico & Shrubs & $\begin{array}{l}\text { Few-layered; only } \\
\text { layer of radially } \\
\text { elongated scler- } \\
\text { eids }\end{array}$ & $\begin{array}{l}\text { Winged } \\
\text { pirenarium }\end{array}$ \\
\hline & Tripterygium & $3 / 3 * * *$ & $\begin{array}{l}\text { Japan, } \\
\text { China, Ko- } \\
\text { rea, Taiwan, } \\
\text { Northern } \\
\text { Myanmar }\end{array}$ & $\begin{array}{l}\text { Scandent } \\
\text { shrubs } \\
\text { (Lianas) }\end{array}$ & $\begin{array}{l}\text { Few-layered; tan- } \\
\text { gential elongated } \\
\text { macrosclereids }\end{array}$ & $\begin{array}{l}\text { Winged } \\
\text { pirenarium }\end{array}$ \\
\hline & Wimmeria & $4 / 12$ & $\begin{array}{l}\text { Central } \\
\text { America }\end{array}$ & $\begin{array}{l}\text { Trees or } \\
\text { shrubs }\end{array}$ & $\begin{array}{l}\text { Few-layered; tan- } \\
\text { gential elongated } \\
\text { macrosclereids }\end{array}$ & $\begin{array}{l}\text { Winged } \\
\text { pirenarium }\end{array}$ \\
\hline & Zinowiewia & $1 / 17$ & $\begin{array}{l}\text { Central and } \\
\text { Southern } \\
\text { America }\end{array}$ & $\begin{array}{l}\text { Trees or } \\
\text { shrubs }\end{array}$ & $\begin{array}{l}\text { Few-layered; tan- } \\
\text { gential elongated } \\
\text { macrosclereids }\end{array}$ & $\begin{array}{l}\text { Winged } \\
\text { pirenarium }\end{array}$ \\
\hline $\begin{array}{l}\text { Other Celastra- } \\
\text { ceae* }\end{array}$ & $\begin{array}{l}91 \text { genera } \\
\text { (from them } \\
39 \text { exam- } \\
\text { ined) }\end{array}$ & $102 / 1170$ & Widely & $\begin{array}{l}\text { Trees, } \\
\text { shrubs, } \\
\text { lianas }\end{array}$ & $\begin{array}{l}\text { Multi- or few- } \\
\text { layered; with } \\
\text { different structure } \\
\text { (sclereids in } \\
\text { meso- or/and } \\
\text { endocarps) }\end{array}$ & $\begin{array}{l}\text { Capsules, } \\
\text { pirenaria**, } \\
\text { nuts**, } \\
\text { berries }\end{array}$ \\
\hline
\end{tabular}

* Mainly according to: Savinov, 2012.

$* *$ never winged

$* * *$ according to original studies 
the basis of a monomerous dry pyrenarium in various representatives of the subfamily Cassinoideae. For the genera Plenckia, Tripterygium, Wimmeria, and Zinowiewia, a similar structure of the pericarp and spermoderm was shown; more isolated in terms of these characters - for Rzedowskia, Ptelidium. Winged fruits of Stackhousioideae are divided and non-homologous to fruits of Tripterygioideae (Savinov et al., 2015).

\section{Conclusion}

The common characters of all studied representatives of the Tripterygioideae can be summarized. 1) Oligomerous gynoecium (2-3, rarely 4-5), usually with 2 ovules per locule. 2) Unilocular one-seeded winged fruits - pyrenaria with remains of style on the apex. 3) Small seeds lacking arils. Two genera appeared to be more isolated - Ptelidium and Rzedowskia, because they have specific characters of pericarp structure (Table). All examined taxa have demonstrated one special evolutional trend in common - the reduction of the number of seeds per fruit and the development of wings as an adaptation to the dispersal by wind.

Acknowledgements. Many thanks to Dr. Mark Simmons (USA) for presenting some articles and his kind assistance in our studies.

Appendix A:

List of vouchers for examined specimens

Plenckia populnea Reiss. (LE, Botanical museum of RAS, St. Petersburg)

Ptelidium ovatum Poir. (P)

P. samberanensis R.Capeen. (P)

Rzedowskia tolantonguensis Medrano (K)

Tripterygium hypoglaucum (Levl.) Hutch. (MHA)

T. regelii Sprague et Takeda (Arboretum of Main Botanical Garden of RAS, Moscow)
T. wilfordii Hook. f. (MHA)

Wimmeria acuminata L. Wins. (LE)

W. bartlettii Lundell. (MHA)

W. confusa Hemsl. (LE)

W. persicifolia Radlk. (LE)

Zinowiewia integerrima Turcz. (Botanical museum of RAS, St. Petersburg)

\section{REFERENCES / ЛИТЕРАТУРA}

Angiosperm Phylogeny Group (APG). 2009. An update of the Angiosperm Phylogeny Group classification for the orders and families of flowering plants: APG III. Bot. J. Linn. Soc. 161: 105-121.

Barykina R. P., Veselova T. D., Devyatov A. G., Dzhalilova Kh. Kh., Il'ina G. M., Chubatova N. V. 2000. Osnovy mikrotekhnicheskikh issledovaniy $v$ botanike. Spravochnoe rukovodstvo. Izdatelstvo kafedry vysshikh rasteniy biologicheskogo fakulteta Moskovskogo gosudarstvennogo universiteta [Basics of microtechnical studies in the Botany: Reference guide. Publishing House of the Vascular plants department of Biological Faculty of Moscow State University, Moscow, 127 pp.] [In Russian]. (Барыкина Р. П., Веселова Т. Д., Девятов А. Г., Джсалилова Х. Х., Ильина Г. М., Чубатова Н. В. Основы микротехнических исследований в ботанике. Справочное руководство. М.: Изд-во каф. высших растений биол. ф-та Моск. гос. ун-та, 2000. 127 с.).

Bobrov A. V., Melikian A. P., Romanov M. S. 2009. Morphogenesis of fruits of Magnoliophyta. Book House "Librokom", Moscow, 400 pp. [In Russian]. (Бобров А. В., Меликян А. П., Романов М. С. Морфогенез плодов Magnoliophyta. М.: Книжный дом «Либроком», 2009. 400 с.).

Coughenour J. M., Simmons M. P., Lombardi J. A., Cappa J. J. 2010. Phylogeny of Celastraceae subfamily Salacioideae and tribe Lophopetaleae inferred from morphological characters and nuclear and plastid genes. Syst. Bot. 35(2): 358-367. URL: http://www.jstor.org/stable/40802448.

Coughenour J. M., Simmons M. P., Lombardi J. A., Yakobson K., Archer R. H. 2011. Phylogeny of Celastraceae subfamily Hippocrateoideae inferred from morphological characters and nuclear and plastid loci. Molec. Phylog. Evol. 59: 320-330.

Gonzalez-Medrano F. 1981. Rzedowskia, un nuevo genero de Celastraceae de Mexico. Bol. Soc. Bot. Mex. 41: $41-46$.

Loesener T. 1942. Celastraceae. In: Die Naturlishen Pfanzenfamilien. Eds. A. Engler, K. Prantl. Wilhelm Engelmann, Leipzig, 20B: 87-197.

Manchester S. R., O'Leary E. L. 2010. Phylogenetic distribution and identification of Fin-winged fruits. Bot. Rev. 76: $1-82$.

Melikjan A. P., Devjatov A. G. 2001. Osnovnye karpologicheskie terminy. Spravochnik [Main carpological terms. Handbook]. Tovareshchestvo nauchnykh izdaniy KMK, Moscow, 47 pp. [In Russian]. (Меликян А. П., Девятов A. Г. Основные карпологические термины. Справочник. М.: Тов-во научн. изд. КМК, 2001. 47 с.). 
Robson N., Halle N., Mathew B., Blakelock R. 1994. Celastraceae. In Flora of Tropical East Africa. Eds. R. M. Polhill, A. A. Balkema. Rotterdam, Brookfield, 1-78 pp.

Savinov I. A. 2012. The levels of fruit organization in Celastraceae and structural diversity of pirenariums in Cassinoideae. Modern Phytomorphology (Lviv, Ukraine) 1: 161-165 [In Russian]. (Савинов И. А. Уровни организации плода в семействе Celastraceae R. Br. и структурное разнообразие пиренариев в подсемействе Cassinoideae Loes. // Modern Phytomorphology, 2012. T. 1. C. 161-165).

Savinov I. A., Trusov N. A., Solomonova E. V., Nozdrina T. D. 2015. Structure, morphogenesis and evolutional transformation of winged fruits in representatives of the family Celastraceae R. Br. Turczaninowia 18, 1: 60-66 [In Russian]. (Савинов И. А., Трусов Н. А., Соломонова Е. В., Ноздрина Т. Д. Структура, морфогенез и эволюционные преобразования плодов с крыловидными выростами у представителей семейства Celastraceae R. Br. // Turczaninowia, 2015. T. 18, вып. 1. C. 60-66). DOI: 10.14258/turczaninowia.18.1.7

Simmons M. P. 2004. Celastraceae. In: The families and genera of flowering plants. Vol. VI. Flowering plants. Dicotyledons. Celastrales, Oxalidales, Rosales, Cornales, Ericales. Ed. K. Kubitzky. Springer, Berlin, 29-64 pp.

Simmons M. P., Bacon C. D., Cappa J. J., McKenna M. J. 2012a. Phylogeny of the Celastraceae subfamilies Cassinoideae and Tripterygioideae inferred from morphological characters and nuclear and plastid loci. Syst. Bot. 37(2): 456-467.

Simmons M. P., Cappa J. J., Archer R. H., Ford A. J., Eichstedt D., Clevinger C. C. 2008. Phylogeny of the Celastreae (Celastraceae) and the relationships of Catha edulis (qat) inferred from morphological characters and nuckear and plastid genes. Mol. Phylog. Evol. 48: 745-757.

Simmons M. P., Clevinger C. C., Savolainen V., Archer R. H., Mathews S., Doyle J. J. 2001a. Phylogeny of the Celastraceae inferred from phytochrome B gene sequence and morphology. Amer. J. Bot. 88(2): 313-325.

Simmons M. P., Hedin J. P. 1999. Relationships and morphological character change among genera of Celastraceae sensu lato (incl. Hippocrateaceae). Ann. Mis. Bot. Gard. 86(3): 723-757.

Simmons M. P., McKenna M. J., Bacon C. D., Yakobson K., Cappa J. J., Archer R. H., Ford A. J. 2012b. Phylogeny of Celastraceae tribe Euonymeae inferred from morphological characters and nuclear and plastid genes. Mol. Phylog. Evol. 62(1): 9-20 [Published on-line: 30 August 2011].

Simmons M. P., Savolainen V., Clevinger C. C., Archer R. H., Davis J. I. 2001b. Phylogeny of the Celastraceae inferred from 26S nuclear ribosomal DNA, phytophrome B, rbcL, atpB, and morphology. Mol. Phylog. Evol. 19(3): 353-366. 